\title{
THE IMPACT OF GOVERNMENT POLICY IMPLEMENTATION ON THE LIMITATION OF IMPORT CATTLE TO COMPANY'S STRATEGY IN THE FRAMEWORK OF MAINTAINING COMPANY PERFORMANCE
}

\author{
Marhendra Audio Valentino Himawan*, Arifin Zainul, Handayani Siti Ragil \\ Faculty of Administrative Science, University of Brawijaya, Indonesia \\ *E-mail: audiovalentinohm@gmail.com
}

\begin{abstract}
This research aims to determine the company's strategy in order to maintain the company's performance as a result of import cattle quota restriction. The policy of import cattle restriction imposed by the Indonesian government certainly has a significant impact on cattle importing companies, especially PT Karunia Alam Sentosa Abadi (KASA), Lampung Indonesia. PT Karunia Alam Sentosa Abadi (KASA) enforces various-new business strategies to maintain the company performance from quota import policy. The results of the study show that there are several strategies applied by the company such as Volume to Performance Strategy, Average Daily Gain (ADG) improvement, Marketing Network Evaluation, Leasing Company Facilities, and Daily Workforce Reduction.
\end{abstract}

\section{KEY WORDS}

Performance, policy, strategic, business.

The inability of local farmers to meet the needs of national meat market makes the government open towards imported cattle and meat. In Indonesia, the main supplier of imported cattle is its neighboring country, Australia. With the introduction of imported cattle and meat, the demand for meat can be met. The level of growth and development of imported cattle in Indonesia is positive from year to year. By that, it is no doubt that Indonesian people become very dependent towards the existence of imported cattle and meat.

The existence of imported cattle then raises the pros and cons in cattle breeding business. The development, growth, and competitiveness of local cattleman tend to be decreased both in the quality and quantity. It happened because Indonesian people rely and dependent more on imported cattle and meat. Besides the price is cheaper, they also have an assumption that imported meat and cattle have better quality than the local.

To solve that dilemma, the government has regulated a policy concerning restriction of imported cattle quota in order to regain competitiveness and development of local cattle through the national beef swasebada (self-sufficiency) in 2012. The policy was established not only to reduce Indonesia's dependence on imported meat but also to improve the performance and competitiveness of local farmers in order to compete with import cattle to export cattle overseas.

The restriction policy of imported cattle quota made by Indonesian government became a controversy and raised some pros and cons. Local cattle was predicted to increase and develop its production, however, it has not been able to balance the needs of the national beef market. The price of national beef is soaring due to its scarcity. In addition, problems also came from cattle importing companies which then experienced a decrease in the performance due to the quota restrictions.

Therefore, the government revised and enforced the policy to become more suitable for the business climate in Indonesia because of the complexity of the problems raised after the implementation of the quota restrictions. The policy of price stability is the next thing enacted by the Indonesian government. In that case, the government is no longer limit cattle import quotas but imposes a benchmark of price to analyze the required amount of imports. Last policy is then enforced by the Indonesian government through President Joko Widodo in which he opened the quota of imported beef up to 220 thousand/cattle per year. 
These policies will greatly affect the performance and activities of imported cattle businessmen or industries. Government policy is fundamental in conducting international business activities. PT Karunia Alam Sentosa Abadi (KASA) is one of the leading companies that concentrate on imported beef business. Certainly, PT Karunia Alam Sentosa Abadi (KASA) is affected directly by the policy that is implemented by the Indonesian government.

A wide variety of business strategy will be discussed and analyzed in order to obtain the most suitable strategy in one of the policies and to survive in the midst of the trouble. Strategies in the areas of marketing, business development, human resources, up to supporting field such as finance, technology, and so on becoming the subjects of this research. These strategies are used to survive in the midst of this chaos. The impact on company's performance is the main purpose of the researcher in this manuscript which is known as defenders Strategies. The business strategy is aimed at curbing the company's performance and maintaining the competitiveness of PT Karunia Alam Sentosa Abadi. Market Share, Profit, Human Resources up to the assets of the company are the variable used by the company in assessing and establishing the best survival strategy for the company.

\section{LITERATURE REVIEW}

\section{Marketing Performance}

Performance is the success indicator of employment or work that is achieved by a person or organization for carrying out their duties properly. Marketing performance is always seen as the result of running a certain strategic role. For a salesperson, the performance generated is a result of aggressive sales approach and good serving on customers (Ferdinand Augusty, 2004 , Sapiro and Witz , 1990). Marketing itself has the definition of a social and managerial process by which the company creates value for customers and builds a strong relationship with customers in order to capture the customers' value in return (Kotler, 2008).

A good marketing performance shows a high level of sales and an increasing number of sales both in product units or in monetary units. The improved marketing performance is marked by good sales growth from the previous year and higher growth than competitors and has a wider market share compared to the previous year. On the other hand, a poor marketing performance is characterized by declining sales, a setback from the previous year or compared to the same industry competitors, and the decline in market share. Related to this, Challagalla and Sharvani (1996) in his research stated that the performance of salesman is a level where the sales force can achieve the sales target set on him.

Kotler (2008) suggested that the success of marketing management is influenced by five alternative concepts underlying an organization or company, among others:

Production Concept. The production concept stated that consumers will love the products that are available and have an affordable price. The management should focus on improving efficiency and its product and distribution.

Sales Concept. It is said that sales concept means consumers will not buy a company's product unless it is sold on a large scale of sales and has big promotional endeavors.

Product Concept. The product concept is a condition where consumers will love the product that offers the best quality, performance, and has innovative features. Organization or company is required to deplete the energy in achieving the goal of this concept which is making a sustainable product improvement.

Marketing Concept. The marketing concept points out that the achievement of an organization or company depends on the knowledge of the needs and demand of the targeted market and satisfaction that is better than the competitor.

(Kotler, Marketing Strategy 2008)

Financial Performance. According to the Institute of Indonesia Chartered Accountants (2009), the definition of financial performance is the relationship between income and entity expenses as presented in the statement of profit and loss. Profit is often used as a 
performance measure or as a basis for other measurements such as return on investment or earnings per share.

Financial management has a central role in the sustainability of a company's financial performance. James C. Van Horne (2012) indicated that financial management is related to asset acquisition, financing, and asset management based on some common objectives that are used to maintain the balance of company's financial performance.

Human Resources Management Performance. Human resources are one of the important components in the life of any organization or company. National Australian Bank Limited in Robbins (2009) said that the greatest strength and the drivers of a company's performance are the workers. National Australian Bank Limited (NAB) is very attentive to the lives of workers or human resources through training and development, work maintenance, and performance appreciation on each worker. It is aimed to maintain the relationship between the organization with the workers as well as to maintain the professional level of the workers. The level of employee professionalism is a general description of human resource performance. A better level of employee professionalism will support the level of company performance.

In a business organization, business management needs to support the operations of the organization in facing several challenges and in achieving the goals of the organization. One of which is by improving the competence and the role of Human Resources (HR). It is important to note that HR is the "soul" of the organization. Many companies who give the portion of duties, responsibilities, and authorities of HR function have not reached the stage of a strategic partner for companies (Swa Sembada Magazine, 2008). One of the dominant factors in this issue is the lack of understanding, both on its company management and managers who are responsible for the HR functions of HR management (HRM) role within the organization. Another factor is the lack of HR manager's understanding of the company's business activities and strategies so that there is no close connection between HR strategy and company strategy. The strategic HR planning that is not implemented properly has made the HR function to be not strategic so that the HR function cannot provide some addition of value for the organization. In this study, the role model of HRM chosen is the model developed by Ulrich (1997), namely (1) the role of HRM as a strategic partner, (2) the role of HRM as a change agent, (3) the role of HR as an employee champion, and (4) the role of HRM as an administrative expert to build strategic HRM role in accordance with PT Karunia Alam Sentosa Abadi (KASA).

Organization Strategy. Developing a strategy means finding a way to achieve the targeted results in accordance with the vision and mission of an organization and its prospect. A strategy is a way to achieve a specific goal or to achieve financial targets and strategic position. Basically, a strategy consists of two things. First, scalable management actions and aims (intended strategy) and secondly, a reaction to an unanticipated development of competitive pressures as government regulations, new business start-ups, and changes in competitor tactics. Management's reaction towards the ongoing development of situation is a tactic to retain the consumers and to withstand the pressures of other market participants.

Management strategy is related to how to raise a company, how to satisfy consumers, how to beat the competition, how to respond the changing market conditions, how to manage each business function, and how to achieve financial goals as well as strategic objectives. A company strategy is specified in accordance with the conditions and situations faced by the company. Companies are free to do any strategy and maneuver to strengthen their competitive position and gain financial benefits.

Business Strategy Description. The main business strategy in the company is how to build and improve the company's position in a long-term business competition. There are 5 principles that must be met, such as:

- Providing an answer or reaction to the ongoing changes in the fields of economy, politics, law, and so on;

- Containing steps and approaches to face the competition;

- Creating competent skills and competencies; 
- Stating the strategic initiatives of each functional department;

- Placing the main strategy of the company's operations.

According to Solihin $(2012,196)$ business strategy is different from the strategy at the corporate level. This business-level strategy is more focused on increasing the competitive position of a company's products or services within a particular market segment. From the above explanation, it can be concluded that business strategy is a strategy to achieve goals in business management which is a guideline for a company's strategic plan to build and strengthen the competitive position of its products or services in the industry.

Business Strategy Level. For large companies, there is a level of management strategy or business that develops in accordance with the development of the business, namely, corporate strategy in holding company, strategy at business unit or division and functional strategy at a business unit. Each of this level can be explained as follows.

Corporate Strategy. Corporate strategy is a strategy run by the company that owns the shares of some other companies (subsidiaries). Such companies are commonly called holding company.

Corporate strategy illustrates the overall direction of the company towards the growth and management of a wide range of business units and product variations identified by the company.

Business Strategy. Business strategy is a strategy that occurs in the division or business unit. This is a strategy that emphasizes the improvement of the competitive position of products or services in specific industries or market segments. A company can have multiple divisions as separate units of strategic business which produce different products. Each division is managed as a semiautonomous unit and is authorized to develop its own strategy within the framework of corporate strategy and objective. The business strategy division may emphasize the increasing profit margins for its products or services. Business strategy should integrate various functional activities so that the goals of the division can be achieved.

Functional Strategy. The functional strategy focuses on maximizing the productivity of resources used in providing the best value to meet customers' needs. The strategy is often called value-based strategy. Being in the constraint of corporate strategy and business unit strategy, each functional department such as production and marketing department will develop a strategy according to the activities and objectives set forth in each department.

Types of Business Strategy. There are several kinds of adaptive strategies developed by Miles and Snow:

Prospector Strategies. This consists of risks taking, looking for opportunities, and doing innovation and development. This strategy is suitable for the dynamic business environment.

Defensive Strategic. Avoid change, give priority to stability, and consider reducing the size of the business, this strategy is suitable for a stable business environment and industry that is in decline.

Reactor Strategic. Responding to the environment without having a long-term strategy design. Companies are merely reactive and short-term oriented.

Analyzer Strategic. Limited in maintaining stability while doing innovation. This strategy lies in the prospector strategy and the reactor strategy. It is usually done by companies that do not become the leader in the market but the follower. In this strategy, the company will follow the leader but also make innovations that are not intensive while waiting for the development of the industry.

\section{METHODS OF RESEARCH}

Types of Research. This study used a qualitative approach because it is made to depict or describe a phenomenon that occurs through words, pictures, tables, and so on. Moleong (2013: 6) stated that qualitative research is a research conducted to understand the phenomena experienced by the subject of the research such as perception, behavior, motivation, and action through the description approach by using words and language. 
Creswell (Miles and Hubermen, 1992) explained that qualitative research is a type of research where researchers are very dependent on the information of the object/participants obtained through broad scope, general questions, data collection consisted largely of words/text from participants, words explanation, and analyzation, and subjective research (Creswell, 2009).

Research Focus. In this case, the focus of the research is divided into several things:

Imported Cattle Policy by the Government of Indonesia: Beef self-sufficiency policy; Limitation of imported cattle quota policy; Beef Price Stability Policy; Cattle Breeders Rate Policy.

Business Strategies of PT Karunia Alam Sentosa Abadi (KASA): Defensive Strategies of PT Karunia Alam Sentosa Abadi (KASA) in facing the cattle importing policy from Indonesia Government; Reactor Strategies of PT Karunia Alam Sentosa Abadi (KASA) in facing the cattle importing policy from Indonesia Government; Analyzer Strategies of PT Karunia Alam Sentosa Abadi (KASA) in analyzing the issues arising from the Indonesian government's cattle import policy.

Performance aspects of PT Karunia Alam Sentosa Abadi: Financial Performance; Assets; Profit.

Non-Financial Performance: Market Shared; Product Quality / Average Daily Gain; Number of Employees / Employee Satisfaction; Business Relationship with the Company; Cattle Importers (Australian Companies).

Research Location and Site. The research was conducted on one fattening corporation of imported cattle in Central Lampung. Precisely, it was in PT Karunia Alam Sentosa Abadi (KASA) at Jalan Pagar Alam II, Kampung Rengas, Bekri Sub-district, Central Lampung.

The research site is in the management office of PT Karunia Alam Sentosa Abadi (KASA) at Jalan Pagar Alam II, Kampung Rengas, Bekri Sub-district, Central Lampung, Indonesia.

Data Source. This research was carried out by using primary data and secondary data obtained from the field, among others:

Primary Data. The informants that researchers use related to the fulfillment of data in this scientific work are: Chief Executive Office or president director of PT Karunia Alam Sentosa Abadi (KASA); Marketing Manager (Marketing Department) of PT Karunia Alam Sentosa Abadi (KASA); Production Director (Production Department) of PT Karunia Alam Sentosa Abadi (KASA); Accountant (Finance Department) of PT Karunia Alam Sentosa Abadi (KASA); Human Resources Manager (Human Resources Department) of PT Karunia Alam Sentosa Abadi (KASA).

Secondary Data. Secondary data in this study were obtained from the Bureau of Statistics, General Directorate of Livestock, Ministry of Agriculture and Ministry of Commerce.

Research Instruments. In collecting the data, research instrument is required to obtain relevant data for the research undertaken. Research instrument is a facility that can be used in collecting data so that the work or activity becomes more organized and produces better result thus it could be processed easily.

In this research, the instruments used were: Interview Guidelines, a number of basic questions that have been prepared beforehand. With this guideline, the verbal answer will be obtained concerning the desired data; Documentation Guidelines to facilitate the learning of documents in the company; Tools used for observation such as our five senses and stationery.

Data analysis technique. Data reduction is referred to as the selection process, focusing on simplification, abstraction, and transformation of data arising from written records in the field. Data reduction is a form of analysis that sharpens, classifies, directs, discards the unnecessary, and organizes the data in such a way that the conclusions can be drawn.

Data presentation can be done in the form of brief descriptions and relationship charts in between categories, flowcharts, and so on. The researcher presents the data in the form of 
descriptive words supported by the presentation of the data table so that it can be clear enough.

Data verification in qualitative research was conducted continuously throughout the study. Since the beginning of entering the field and during the process of data collection, the researchers tried to analyze and find the meaning of the collected data such as looking for patterns, themes, equation relationships, things that often arose, and etc poured in the conclusion that is tentative.

\section{DISCUSSION OF RESULTS}

Business Strategy Analysis in Financial Field. The dependence of PT Karunia Alam Sentosa Abadi (KASA) on the existence of imported cattle is, of course, experiencing such ups and downs in its performance both financially and non-financially. The decline in the financial benefits of PT Karunia Alam Sentosa Abadi (KASA) is certain to occur when the policy on quota import restrictions is applied by the Indonesian government. Limitation of beef imports is clearly depressing the sales figures as well as the rate of profit. It is also explained by the Accounting Officer of PT Karunia Alam Sentosa Abadi (KASA), Hendrik Yulianto in which he said "the restriction of cattle import quota is greatly reducing the number of cattle sales to the customer. Besides that, there will be a turmoil in which the overhead cost that has been designed will be a burden because the company's revenue is stuttering" (Statement in Bahasa Indonesia: "Pembatasan kuota impor sapi sangat menekan angka penjualan sapi kepada para customer. Disamping itu, akan timbul gejolak dimana overhead cost yang telah dirancang akan menjadi beban dikarenakan pemasukan perusahaan yang tersendat') (Source: Interview with Accounting Officer of PT Karunia Alam Sentosa Abadi (KASA), Hendrik Yulianto, December 20th, 2016, 09:30 in Office). From the statement, it is clear that the restriction of cattle import quota greatly affects the financial performance of PT Karunia Alam Sentosa Abadi (KASA) referenced from the increase of overhead cost and the reduction of income or profit.

In this case, PT Karunia Alam Sentosa Abadi (KASA) uses a relatively similar survival strategy when the cattle import quota policy is determined by cost efficiency. It is known that PT Karunia Alam Sentosa Abadi (KASA) endures cost efficiency in several forms, namely:

Production cost efficiency. Cost efficiency of production is an efficiency to the cost of feed and cattle treatment. PT Karunia Alam Sentosa Abadi (KASA) formed a team under the command of Director of Operational and Production to conduct a research. The research was intended to investigate and search for alternative feeding material by utilizing the side product of agro-industry in Lampung like palm, tapioca starch, and sugar cane. This may depress the production cost due to the cattle import restriction policy and price stability policy because companies will use the alternative feed from other industrial products. Alternative feed has a cheaper price than the concentrate feed. However, the nutrition must be assessed in depth so that the cattle could get proper food supply and boosted the Average Daily Gain (ADG) maximally. The CEO of PT Karunia Alam Sentosa Abadi (KASA), Didiek Purwanto said that "alternative feeding should continue to be followed related to its nutritional content and that the ADG is not reduced. Cows have the ability to synthesize the protein very well".

Indirect cost efficiency. In indirect cost efficiency, there are several strategies set by PT Karunia Alam Sentosa Abadi (KASA) in the midst of the turmoil of government policy. First, the cost-efficiency of human resources by cutting the number of casual labor or daily labor. The explanation of human resource strategy will be discussed deeply in the human resource sub-chapter. In this case, the deduction or efficiency of the number of employees is only intended to reduce the overhead cost which was escalated when the stock of imported cattle was limited. After that, the arrangement between the in and out of the cattle should be more clear and definite. By that, PT Karunia Alam Sentosa Abadi (KASA) has pressed the government concerning the exact number of import quotas given to the company. This is because if the number is unclear, it can affect the credit cooperation with the Bank. Bank as 
a business partner who provides loans to PT Karunia Alam Sentosa Abadi (KASA) certainly does not want such kind of uncertainty in the business.

Corporate Facility Strategies. PT Karunia Alam Sentosa Abadi (KASA) also made a new strategy in the context of financial efficiency after the turmoil of government policy by leasing the production facilities owned by the company to other companies or business partners. Differences in the number of import quota between each company or business actor become the fundamental reason for forming this strategy. CEO of PT Karunia Alam Sentosa Abadi (KASA), Didiek Purwanto said that "We're going to lease our facilities to business partners or other feed lotter company. Because of the policy, this makes the company get different quotas for each company. This underlies us to lease our facilities so as not to experience a vacuum or a reduction in quality" (Statement in Bahasa Indonesia: "Kita akan sewakan fasilitas operasional yang perusahaan miliki kepada mitra bisnis atau perusahaan feedlotter lainnya. Karena pembatasan kuota impor sapi yang dicanangkan pemerintah , membuat perusahaan mendapatkan jatah atau kuota yang berbeda - beda. Hal ini kemudian yang melandasi kami untuk menyewakan fasilitas yang kami miliki agar tidak mengalami kekosongan atau pengurangan kualitas") (Source: Interview with the CEO of PT Karunia Alam Sentosa Abadi (KASA), Didiek Poerwanto, December 20th, 2016, 08:30 in the Office).

Market Segmentation. PT Karunia Alam Sentosa Abadi (KASA) categorizes the customers based on the region and slaughterhouse (Rumah Potong Hewan) accreditation. By region, the market of PT Karunia Alam Sentosa Abadi (KASA) consists of 2 regions such as Sumatra and Java. When the cattle import quota policy is applied, the stock or the population of imported cattle from PT Karunia Alam Sentosa Abadi (KASA) will be depleted. It will cause additional problems if there are issues outside the operational issues such as death during delivery, cow stress during delivery, and others. Therefore, PT Karunia Alam Sentosa Abadi (KASA) will also limit the delivery or sale of cattle to Java due to the distance between Sumatra and Java which is too far and risky. PT Karunia Alam Sentosa Abadi (KASA) send or sell more cattle to Sumatra with a percentage of market segmentation by $75 \%$ in Sumatra and $25 \%$ in Java. Besides to minimize the occurrence of cattle death during delivery, PT Karunia Alam Sentosa Abadi (KASA) also able to maintain the level of competition with other companies related to the quality of the meat and the weight of the cattle if competing in Sumatran market that is near the company location. This is confirmed by the CEO of the company, Didiek Purwanto. He said that "The product of this company will certainly able to win the competition if it has a good quality in accordance with the volume strategy applied to performance. Therefore, the company should be able to minimize any gap that can reduce the quality or performance of the cattle by cutting the cost or market risk arising from distance delivery. $75 \%$ of the market segmentation will be put to Sumatra, this is certainly close to our farm" (Statement in Bahasa Indonesia: "Produk dari KASA tentu akan lebih mampu memenangkan kompetisi apabila memiliki kualitas yang baik, sesuai dengan strategi volume to peformance yang diterapkan. Maka dari itu, perusahaan harus mampu meminimalisir setiap celah yang dapat mengurangi kualitas atau peformance dari sapi tersebut dengan cara memotong biaya atau resiko pasar yang muncul akibat terlalu jauhnya jarak pengiriman sapi. Maka dari itu $75 \%$ market segmentation dari PT KASA akan menuju ke Sumatera yang tentunya dekat dengan Farm KASA") (Source: Interview with Purchasing CEO of PT Karunia Alam Sentosa Abadi (KASA), Didiek Poerwanto, December 27, 2016, $12: 30$ in the Office).

Product Positioning. PT Karunia Alam Sentosa Abadi uses the Average Daily Gain and the color of the beef to determine product positioning. The Production Director of PT Karunia Alam Sentosa Abadi (KASA), Gunawan said that "the Average Daily Gain and color of meat is the main thing that becomes the concern of our company when it is ready to sell to the public. Attractive color of meat and good cattle weight will support the level of sales so that customer will be interested to buy cattle from our company" (Statement in Bahasa Indonesia:"Average Daily Gain dan warna daging adalah hal utama yang perusahaan perhatikan ketika menjualnya ke publik. Warna daging yang menarik serta berat badan sapi yang baik akan menunjang tingkat penjualan serta membuat customer akan tertarik untuk 
membeli sapi dari KASA.) (Source: Interview with Production Director of PT Karunia Alam Sentosa Abadi (KASA) Gunawan, December 27, 2016, 13:30 in the Office). It is said that the higher level of Average Daily Gain (ADG), the higher the price of the cattle in the market.

Price. Furtherly, the marketing strategy run by PT Karunia Alam Sentosa Abadi (KASA) is the price of benefits. The price of benefits means that the company is responsible for the prices charged to the buyer with the performance level of the cattle. The price offered by PT Karunia Alam Sentosa Abadi (KASA) will always be followed by the Average Daily Gain rate, the color of the meat, and the health level of the cattle. The company uses this strategy to generate some additional values when the customers purchase the products which in turn makes the customers become the automatic promotion tool of the company.

Promotion. The promotion strategies carried out by PT Karunia Alam Sentosa Abadi (KASA) is to educate the customer. PT Karunia Alam Sentosa Abadi formed a campaign team containing staff marketing and Animal Warfare Officer to perform an education-related to cattle and communicate intensely with customers in order to listen to the complaints that arise. CEO of PT Karunia Alam Sentosa Abadi (KASA), Didiek Purwanto said that "KASA gives an education to the customers and slaughterhouse related to cattle treatment and things related to Animal Warfare. This was done because we want some kind of connection in between the company and the customer. We hope that through this education, the customer will aware that we care about them and, eventually, they will become a promotional tool for our company. This education activity is intended to generate some added value for the company" (Statement in Bahasa Indonesia: "KASA memberikan edukasi kepada para customer dan Rumah Potong Hewan terkait perawatan sapi dan hal hal yang terkait dengan Animal Warfare. Hal ini kami lakukan dengan maksud ada keterikatan batin antar perushaan dengan customer. Kami berharap dengan edukasi ini customer merasa diperhatikan oleh PT KASA dan pada akhirnya mereka akan menjadi alat promosi bang KASA. Edukasi ini kami lakukan untuk emnambah added value dari perusahaan" (Source: Interview with the CEO of Pt Karunia Alam Sentosa Abadi (KASA) Didiek Poerwanto, December 27, 2016, 12:30 in the Office).

Production Performance. Initially, the transfer of a business mindset of PT Karunia Alam Sentosa Abadi (KASA) was oriented on volume and then changed to the orientation of performance. This makes PT Karunia Alam Sentosa Abadi (KASA) have excellent cattle quality. The strategy issued by PT Karunia Alam Sentosa Abadi (KASA) is to increase the performance of the cattle through the increasing Average Daily Gain (ADG) program. The program to increase ADG is done because the small stock of cattle can be covered through cow maximum weight determination because the calculation of cattle prices is based on the weight of the cattle. The Director of Operations and Production of PT Karunia Alam Sentosa Abadi (KASA), Gunawan said that "ADG is the key to maintaining the market share of PT Karunia Alam Sentosa Abadi (KASA). The growth of ADG is very concerned because the stock of imported cattle is continuously reduced by the government. Maximum ADG will make the cattle becomes expensive in the market" (Statement in Bahasa Indonesia: "ADG menjadi kunci PT KASA dalam mempertahankan market share. Pertumbuhan ADG sangat diperhatikan ditengah stok sapi impor yang terus menerus dikurangi oleh pemerintah. ADG yang maksimal tentu akan mebuat harga sapi menjadi mahal di pasar" (PT Karunia Alam Sentosa Abadi (KASA), 28 December 2016 , 08:30).

The growth rate of cattle's ADG is determined by the nutrition and feed that is regularly given and nutritious. This can be minimized very well by PT Karunia Alam Sentosa Abadi (KASA) through the utilization of waste or side-products from industries in Sumatra. Then, it is processed to produce an alternative feed source for maximum nutrition but with cheap cost.

\section{CONCLUSION}

The existence or establishment of government policies has affected the business conditions in a country. The determination of cattle import policy that starts from imported cattle quota restriction, price stability policy, until the cattle breeding ratio policy is considered 
as a major influence on the performance of cattle importing companies, one of which is PT Karunia Alam Sentosa Abadi (KASA).

Business strategies will change to follow the conditions and business environment particularly in a situation that is set by the Indonesian government. The new strategy in every division of the company such as marketing, finance, production, business relations, and human resources will be applied based on the conditions and business environment that are constantly changing. The efficiency of all company became the basis to prepare new strategy as a strategy of volume to performance, nutrition and feeding alternative strategy, market allocation strategy, and the effectiveness of human resources strategy. All of those strategies are done in order to survive the company's balance sheet so that it will not have a deficit. The defensive strategies are also implemented to maintain the value of the company and the value of competence in the eyes of the customer.

\section{SUGGESTIONS}

PT Karunia Alam Sentosa Abadi (KASA) should be able to survive all business situations and environmental conditions. The company should be able to survive and keep the rhythm of the business in the midst of the turmoil of this government policy. Each element of the company such as finance, marketing, production, and human resources must be up to date and able to adapt quickly to changes that arise from the internal and external side. The relationship with the Indonesian government become the main point that must be maintained and kept beneficially. This is because any government policies will affect the continuity of PT Karunia Alam Sentosa Abadi (KASA) business.

Moreover, cattle import policy implemented by Indonesian government has a very positive impact on the cattle business continuity, especially for local cattle farmers. Selfsufficiency program of national beef is a form of government's seriousness in improving the quality of Indonesian cattle. However, the government must consider the facts that the presence of local cattle still not able to offset the need for national beef/cattle in which this resulted in scarcity and price inflation of beef. In this issue, the cattle importing company will be harmed with the implementation of this policy. The restricted stock of cattle will make the company to find a way in surviving this condition.

\section{REFERENCES}

1. Aaker, D.A. 2013. Manajemen Pemasaran Strategi. Eight Edition. Salemba Empat. Jakarta.

2. [APFINDO] Asosiasi Pengusaha Feedlot Indonesia. 2011. Realisasi Impor Sapi Bakalan. Sekretariat APFINDO. Jakarta

3. Brealey, R.A., Myers,S.C., \& Marcus,A.J. 2007. Fundamental of Corporate Finnance. Sabran, Bob Jilid 1 Edisi Kelima. PT. Erlangga. Jakarta

4. Creswell, J.W. (2010). Research design: pendekatan kualitatif, kuantitatif, dan mixed. Yogjakarta: PT Pustaka Pelajar.

5. Dafid, F.R. (2010). Manajemen Strategis. Salemba Empat. Jakarta

6. Robbins, S.P. \& Coulter, M. (2010). Manajemen Edisi 10 Jilid 1. Jakarta: Erlangga.

7. Susanto, A.B. 2014. Manajemen Strategik Komprehensif untuk Mahasiswa dan Praktisi. Penerbit Erlangga, Jakarta

8. Van Horne, J. 2012. Prinsip-Prinsip Manajemen Keuangan Edisi 13. Jakarta. Salemba Empat 